\title{
Effects of Inorganic Nitrogen Enrichment on Lake Huron Phytoplankton: An Experimental Study
}

\author{
Janice L. Pappas and Eugene F. Stoermer \\ Center for Great Lakes and Aquatic Sciences \\ University of Michigan \\ Ann Arbor, Michigan 48109-2099
}

\begin{abstract}
Effects of inorganic nitrogen $\left(\mathrm{NO}_{3}\right)$ enrichment on phytoplankton were studied using a factorial design experiment. Using species assemblages from Lake Huron waters, the effects of $\mathrm{NO}_{3}$ and total phosphorus (TSP) additions on species abundance and composition were monitored. The speciesnutrient relationship was determined by canonical correspondence analysis (CCA). In addition, divisional differences were related to nutrient additions using correspondence analysis $(C A)$. These techniques were instrumental in developing species relationships to $\mathrm{NO}_{3}$ and TSP gradients and, by partialling out the effect of TSP to determine the primary species- $\mathrm{NO}_{3}$ relationship. Nitrate-phosphorus $(N: P)$ effects were also analyzed at the species and divisional levels. Gross changes in biomass, as represented by chlorophyll a concentrations, were not evident from $\mathrm{NO}_{3}$ enrichment. However, species composition did change, particularly for a few species. Most evident were increases in relative abundance of Cyclotella comensis. Cyclotella stelligera, Fragilaria capucina, F. pinnata, and flagellates showed similar increased proportional abundance. Flagellates responded positively to both $\mathrm{NO}_{3}$ additions and $\mathrm{N}: \mathrm{P}$ interactions. Overall, there were not great changes at the level of major algal divisions. All major groups maintained their abundances relative to one another throughout the experimental period. The results from this study showed that increased $\mathrm{NO}_{3}$ levels in the Great Lakes would affect species composition.
\end{abstract}

INDEX WORDS: Lake Huron, phytoplankton, inorganic nitrogen.

\section{INTRODUCTION}

Investigations of nutrient loadings to aquatic systems have been a matter of great interest for some time (Likens 1972). In most instances, in the 1970s, nutrient loadings were perceived as local problems to be resolved. Abatement programs have primarily reduced phosphorus loadings, which have been effective in reducing algal biomass (Bierman and Dolan 1986a, 1986b). However, controls instituted thus far have not returned Great Lakes primary producer communities to conditions prior to the 1970 s (Wolin et al. 1988).

In the Great Lakes, relationships between nutrients and phytoplankton species composition have been altered in two major ways. Increased phosphorus loadings resulted in reduced nitrogen (Dobson 1984) and silica (Schelske and Stoermer 1971) concentrations because of increased algal production. Nitrogen concentrations have subsequently increased from atmospheric loadings. In Lake Ontario the concentration of inorganic nitrogen $\left(\mathrm{NO}_{3}\right)$ has been increasing since the mid-1970s (Stevens
1988). Changes in species composition may be a result of changes in N:P (Smith 1983).

In the other Great Lakes, there is also evidence of large-scale changes in species composition with relatively small changes in biomass (Makarewicz 1987, 1988). In all these lakes there has been eutrophication, then abatement of pollution, but this was followed by alterations in species composition rather than a return to the previous known phytoplankton assemblages.

In this regard, attention has turned to more subtle and global considerations. Atmospheric $\mathrm{NO}_{3}$ loadings are an emerging problem which is beginning to be recognized on a world-wide basis (Dickson 1982, 1986; Smith et al. 1987; Brown 1988). This problem is especially relevant to the Great Lakes because of their long water residence times and because approximately one-third of their total water budget originates directly from precipitation on the lakes' surfaces.

In past studies of enrichment of the Great Lakes, the focus has been on the effects of a limiting nutrient on natural phytoplankton assemblages 
(Schelske and Stoermer 1972). These studies were mainly concerned with phosphorus loadings and eutrophication, or silica depletion and changes in trophic status (Schelske and Stoermer 1971, 1972; Schelske et al. 1983). In some nutrient enrichment studies, $\mathrm{NO}_{3}$ effects were found to have a secondary effect but not directly investigated (Stoermer et al. 1978). This suggests the need for inquiry into the relationship between $\mathrm{NO}_{3}$ concentrations, phytoplankton assemblage composition, and other ecosystem changes.

The purpose of this experimental study is threefold. First, if biomass does not change drastically from $\mathrm{NO}_{3}$ enrichment, are there changes in an assemblage at the species level or division level? Second, are N:P effects evident? Finally, how do the results of this study relate to natural Great Lakes assemblages?

\section{MATERIALS AND METHODS}

Surface water from Lake Huron was collected south of the Blue Water Bridge, Port Huron, Michigan on 11 June 1991 at midday. Large zooplankton were excluded by passing water through a $212 \mu \mathrm{m}$ mesh sieve. Water was randomly distributed to 16 20-L carboys for the experiment and 1 10-L carboy for measurement of initial conditions. Water temperature at the time of collection was $17.6^{\circ} \mathrm{C}$.

Carboys were transported to Ann Arbor, Michigan in dark, insulated enclosures to maintain initial conditions. Carboys were placed in an environmental chamber set at 16:8-h LD cycle, irradiance of 50 $\mu$ Ein $\mathrm{m}^{-2} \mathrm{~s}^{-1}$ and $15^{\circ} \mathrm{C}$ for the duration of the 20 day experimental period.

The factorial experimental design consisted of 15 treatments of five nitrate $\left(\mathrm{NO}_{3}\right)$ concentration levels and three total phosphorus (TSP) concentration levels. Each treatment was designated $\mathrm{A}$ through $\mathrm{O}$ (Fig. 1). An additional treatment, designated P, received additions of filtered rainwater to produce a total concentration of $1 \%$ rainwater throughout the experimental period (Fig. 1). Ambient silica $\left(\mathrm{SiO}_{2}\right)$ concentrations were maintained throughout the experiment in all treatments. All carboys were shaken prior to subsampling and at least once a day.

Nitrate and TSP levels chosen for this experiment were based on a similar experiment conducted in 1971 (Stoermer et al. 1978). In that experiment, secondary effects were produced with $\mathrm{NO}_{3}$ levels at 225,839 , and $1,120 \mu \mathrm{g} \mathrm{N} \mathrm{L}^{-1}$. Concentrations of $60,120,240,480$, and $960 \mu \mathrm{g} \mathrm{N} \mathrm{L}^{-1}$ were chosen as the $\mathrm{NO}_{3}$ levels for the 1991 experiment. In the 1971 experiment, TSP levels at 5 and $15 \mu \mathrm{g} \mathrm{P} \mathrm{L}^{-1}$ had the
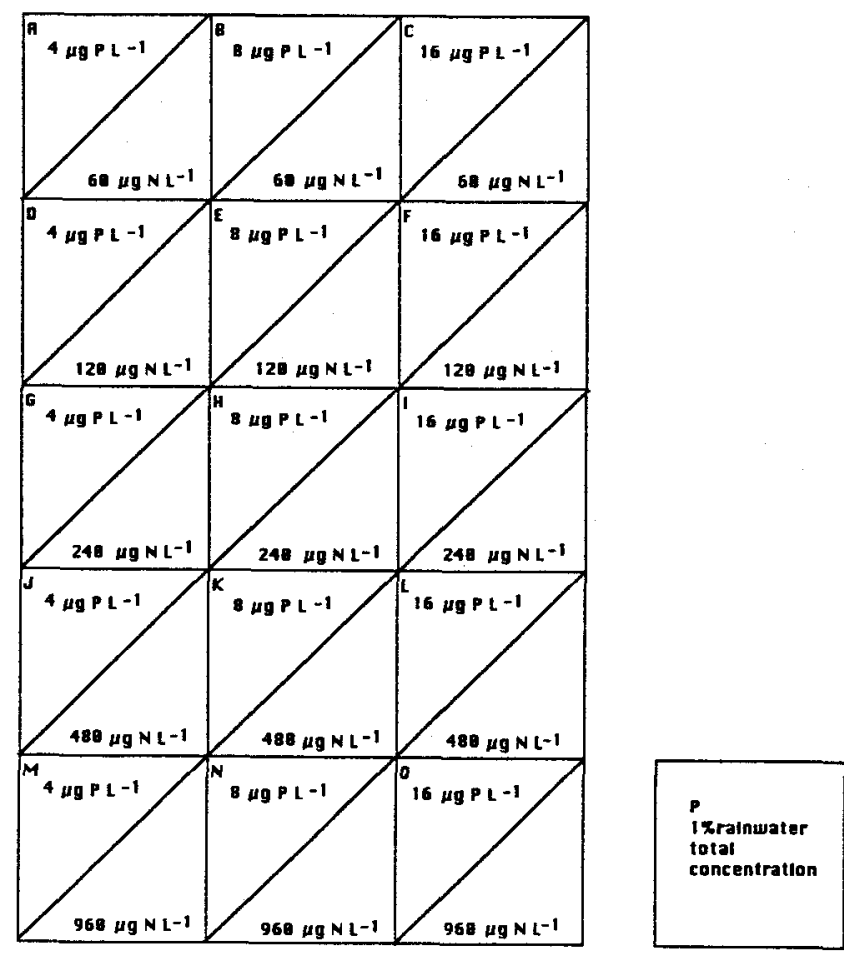

FIG. 1. Factorial nutrient additions of $N$ and $P$. Letters in the upper lefthand corner represent designation of carboys associated with the specific treatment. Silica was maintained at ambient concentration.

least effect on species. Concentrations of 4,8 , and $16 \mu \mathrm{g} \mathrm{P} \mathrm{L}^{-1}$ were chosen as the TSP levels for the 1991 experiment. With similar $\mathrm{N}$ and $\mathrm{P}$ concentrations, the 1971 and 1991 experimental results can be compared. By minimizing TSP effects with the levels chosen for the 1991 experiment, primary $\mathrm{NO}_{3}$ effects can be determined.

Throughout the 20-day experimental period, nutrient concentrations were maintained for all treatments by additions of stock solutions. These solutions were added in quantities small enough to change the total volume of each treatment as little as possible. Stock solutions were made from analytical reagent grade potassium phosphate monobasic $\left(\mathrm{KH}_{2} \mathrm{PO}_{4}\right)$, potassium nitrate $\left(\mathrm{KNO}_{3}\right)$, and sodium meta-silicate $\left(\mathrm{Na}_{2} \mathrm{SiO}_{3} \bullet 9 \mathrm{H}_{2} \mathrm{O}\right)$ for $200 \mathrm{mg} \mathrm{L}^{-1} \mathrm{TSP}$, $1,000 \mathrm{mg} \mathrm{L}^{-1} \mathrm{NO}_{3}$, and $2,000 \mathrm{mg} \mathrm{L}^{-1} \mathrm{SiO}_{2}$, respectively.

To monitor nutrient concentrations, $150200-\mathrm{mL}$ subsamples were filtered from each treatment every 2 days and measured colorimetrically on a Techni- 
con Autoanalyzer (Schelske et al. 1974). Every 3 days, $250500-\mathrm{mL}$ subsamples were filtered for chlorophyll $a$ determination (Schelske et al. 1974), and 50-mL subsamples were fixed with glutaraldehyde and filtered for species enumeration (Stoermer et al. 1971). All subsamples were taken in triplicate. For further explanation of the factorial experiment see Schelske et al. 1974. For further explanation of slide preparation and species enumeration see Stoermer et al. 1978.

Statistical analyses were performed using canonical correspondence analysis (CCA), correspondence analysis (CA), and detrended correspondence analysis (DCA) from the statistical package CANOCO (ter Braak 1988). CCA is designed to relate environmental variables to species abundance based on weighted averaging. Species response curves are unimodal, and the optima or weighted averages represent the maximum responses to an environmental variable. Eigenvectors were extracted such that sample scores (representing treatments) were a linear combination of the environmental variables. The resultant constrained ordination was scaled to include all samples, species, and environmental variables in the same diagram. A Monte Carlo permutation test was performed on the total number of constrained axes to determine significance (ter Braak 1988, 1990). DCA was used to develop a time gradient with respect to the species assemblage. Detrending removes the arch effect on the second eigenvector so that the resultant ordination shows the major gradient to be the first eigenvector. CA was used to develop a time gradient with respect to divisions.

A purpose of this study was to determine change in species composition in the context of an assemblage where $\mathrm{N}$ and $\mathrm{P}$ are interdependent variables. Therefore, this a multivariate problem. Using CCA, $\mathrm{CA}$, and DCA to determine $\mathrm{N}, \mathrm{P}$, and $\mathrm{N}: \mathrm{P}$ effects produces multivariate analyses of variance (ter Braak 1990). CA and DCA are indirect gradient analytical techniques. CCA is a direct gradient analytical technique which produces a decomposition of total variance. Total variance in the species data is represented by the sum of all unconstrained eigenvalues. Total variance in the fit of species data to the environmental variable, $\mathrm{N}$ or $\mathrm{P}$, is represented by the sum of all constrained eigenvalues. The eigenvalues may be represented as percentages for each constrained axis. CCA determines the linear combination of $\mathrm{N}$ and $\mathrm{P}$ which maximizes species variance. Partial CCA is suited to determine species variation with respect to $\mathrm{N}$ by taking into account the effects of $P$ as a covariable. This is a useful way to determine N-P interaction. CCA is an effective technique to determine species-environment relationships in this multivariate ecological problem.

\section{RESULTS}

For 11 June 1991, initial $\mathrm{NO}_{3}$ concentration was $330 \mu \mathrm{g} \mathrm{L}^{-1}$. This was greater than the proposed $\mathrm{NO}_{3}$ additions of 60,120 , and $240 \mu \mathrm{g} \mathrm{L}^{-1}$ to carboys A-I. The initial $\mathrm{NO}_{3}$ concentration never fell below 240 $\mu \mathrm{g} \mathrm{L}^{-1}$ during the course of the experimental period. Therefore, carboys A, D, and G were considered replicates as were carboys $\mathrm{B}, \mathrm{E}$, and $\mathrm{H}$ and carboys $\mathrm{C}, \mathrm{F}$, and I. As a result, carboys $\mathrm{A}, \mathrm{B}$, and $\mathrm{C}$ were used. Initial TSP concentration was $3.5 \mu \mathrm{g} \mathrm{L}^{-1}$. Ambient $\mathrm{SiO}_{2}$ concentration was $350 \mu \mathrm{g} \mathrm{L}^{-1}$.

Initially, $\mathrm{NO}_{3}$ concentration for carboy $\mathrm{P}$ was 330 $\mu \mathrm{g} \mathrm{L}^{-1}$. By the end of the experiment, $\mathrm{NO}_{3}$ levels were $450 \mu \mathrm{g} \mathrm{L}^{-1}$. This represents an increase of 120 $\mu \mathrm{g} \mathrm{L}^{-1} \mathrm{NO}_{3}$ from rainwater additions.

In general, biomass, as represented by chlorophyll $a$ concentration, increased exponentially as the experiment progressed (Fig. 2). Except for carboy $\mathrm{L}$, chlorophyll $a$ concentrations ranged from 2 to $6 \mu \mathrm{g} \mathrm{L}^{-1}$. On Day 9, and thereafter, carboy $\mathrm{L}$ departed from the rest of the treatments. In terms of biomass as well as species abundances and enumeration from slides, carboy $\mathrm{L}$ appeared to be contaminated. Many of the species present were periphytic forms. Comparison of species composition with

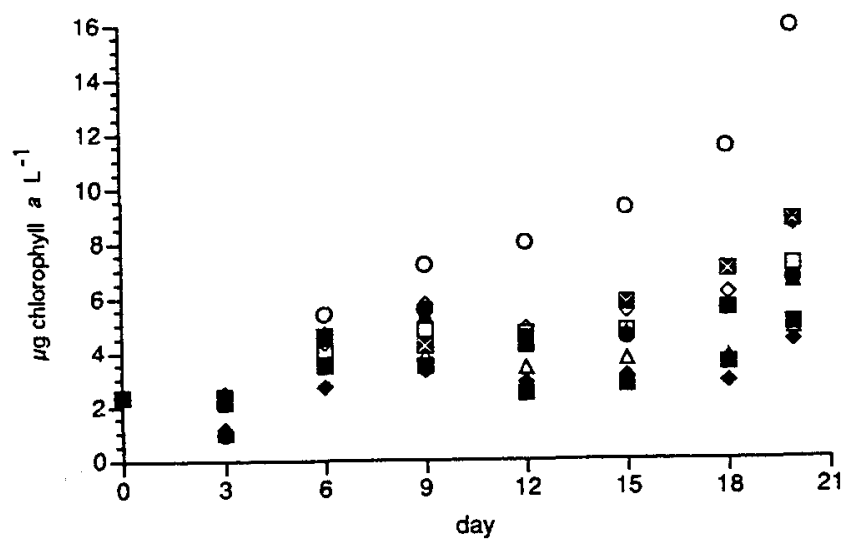

FIG. 2. Chlorophyll a concentration for each treatment for the June 1991 experimental period. The treatments are represented by the following symbols: A - $\square$; B -O; C - A; J - ; K $\square ; L-\bigcirc$; $M-\triangle ; N-\diamond ; O-\ltimes$ 
other treatments was untenable. As a result, carboy $\mathrm{L}$ was not included in any further analysis.

Over 220 taxa were identified. For statistical analyses, only those taxa which occurred at abundance levels of greater than $1 \%$ for at least the majority of the subsampling days were used. Asterionella formosa, Crucigenia quadrata, Cyclotella comensis, C. michiganiana, $C$. ocellata, $C$. pseudostelligera, Cyclotella sp., C. stelligera, Fragilaria capucina, $F$. crotonensis, $F$. pinnata, Rhizosolenia eriensis, Synedra filiformis, Tabellaria fenestrata, and Tetraedron minimum qualified, representing six genera of Bacillariophyta and one genus of Chlorophyta. In addition, a composite group of flagellates was included.

CCA was performed on data for each subsampling day. To represent the species-environment relationships with respect to time, ordination diagrams were constructed with species scores, sample scores representing carboys, and biplot scores of the environmental variables, $\mathrm{NO}_{3}$ and TSP. In addition, TSP was used as a covariable. $\mathrm{SiO}_{2}$ was a constant, and therefore was not used as an environmental variable or covariable. The number of canonical eigenvectors extracted represent the number of environmental variables used in the analysis. Since two environmental variables were used, two constrained and two residual axes resulted. Species scores were centroids of sample scores, and biplot scores represented the heads of the environmental arrows. Species which were most abundant occurred near the origin. Species scores which were near sample scores implied that the species occurred in that sample. The head of the $\mathrm{NO}_{3}$ arrow represented high $\mathrm{NO}_{3}$ concentration, and the end of the arrow represented low $\mathrm{NO}_{3}$ concentration. The magnitude of the $\mathrm{NO}_{3}$ arrow throughout the experiment was larger than the TSP arrow. The $\mathrm{NO}_{3}$ arrow represents a linear gradient. Perpendiculars from species scores to this arrow represent the maximum height of each species response curve. Therefore, species scores are optimal responses to $\mathrm{NO}_{3}$ and are approximate weighted averages. The scores nearest the head of the arrow were most influenced by $\mathrm{NO}_{3}$. Those farthest from the head of the arrow were least influenced. An example of a CCA ordination for Day 6 is depicted in Figure 3.

Except for Day 9, $\mathrm{NO}_{3}$ influenced the major gradient along the first constrained axis from Day 3 to Day 12. A shift occurred from Day 15 to Day 20 in which the major gradient became TSP. At some time between Day 12 and Day 15, no species was optimally influenced by $\mathrm{NO}_{3}$.

For each subsampling day a number of numerical tests were performed to further characterize the data. Interset correlation coefficients were calculated to determine the strength of the relationship between the environmental arrows and each of the constrained axes (Table 1). Days 3, 6, and 12 showed the $\mathrm{NO}_{3}$ arrow to be positively correlated with the first constrained axis. Day 9 showed the $\mathrm{NO}_{3}$ arrow to be positively correlated while Days 15 and 20 were negatively correlated to the second constrained axis. For Day 18 , the $\mathrm{NO}_{3}$ arrow was negatively correlated with the first constrained axis, but not decisively so. TSP was positively correlated to the first constrained axis at almost an equal amount.

Eigenvalues for each canonical axis were calculated. For each subsampling day, canonical eigenvalues ranged from 0.06 to 0.134 for the first constrained axis, and 0.01 to 0.07 for the second constrained axis (Table 2). The sum of both canonical axes resulted in eigenvalues ranging from 0.09 to 0.20 . All eigenvalues represent residual variances after fitting the covariable TSP. The percentage of the variance of the species-environment relationship ranged from 54 to $95 \%$ for the first constrained axis (Table 3 ). That is, a majority of the variation was accounted for by the first constrained axis. The percentage of the variance of the species data for the first constrained axis ranged from 12 to $39 \%$ (Table 3 ). It is not uncommon to find low eigenvalues in ecological data; even a low percentage of the variance explained still can be informative (ter Braak 1988).

A restricted Monte Carlo permutation test was performed to determine the significance of the canonical axes (Table 4). This test was structured on a repeated measurement design where the covariable TSP conditioned the test as three blocks. The first block included treatments $\mathrm{A}, \mathrm{B}$, and $\mathrm{C}$ which had low $\mathrm{NO}_{3}$ concentrations. The second block included treatments $\mathrm{J}$ and $\mathrm{K}$ which had mid $\mathrm{NO}_{3}$ concentrations. The third block included the high $\mathrm{NO}_{3}$ concentration treatments of $\mathrm{M}, \mathrm{N}$, and $\mathrm{O}$. The test was conducted using 99 permutations. The results showed that Days 6,12, and 15 had p-values of $<0.05$ for the trace, and therefore had significant canonical axes.

Those species most influenced by $\mathrm{NO}_{3}$ for each day are given in Table 5. Some species occurred in somewhat specific patterns. Cyclotella kutzingiana occurred on Days 3,6, and 9, but then did not occur again until Day 20. Fragilaria construens and $F$. construens var. venter occurred on Days 12, 15, and 18 rather than early in the experiment. Gomphos- 


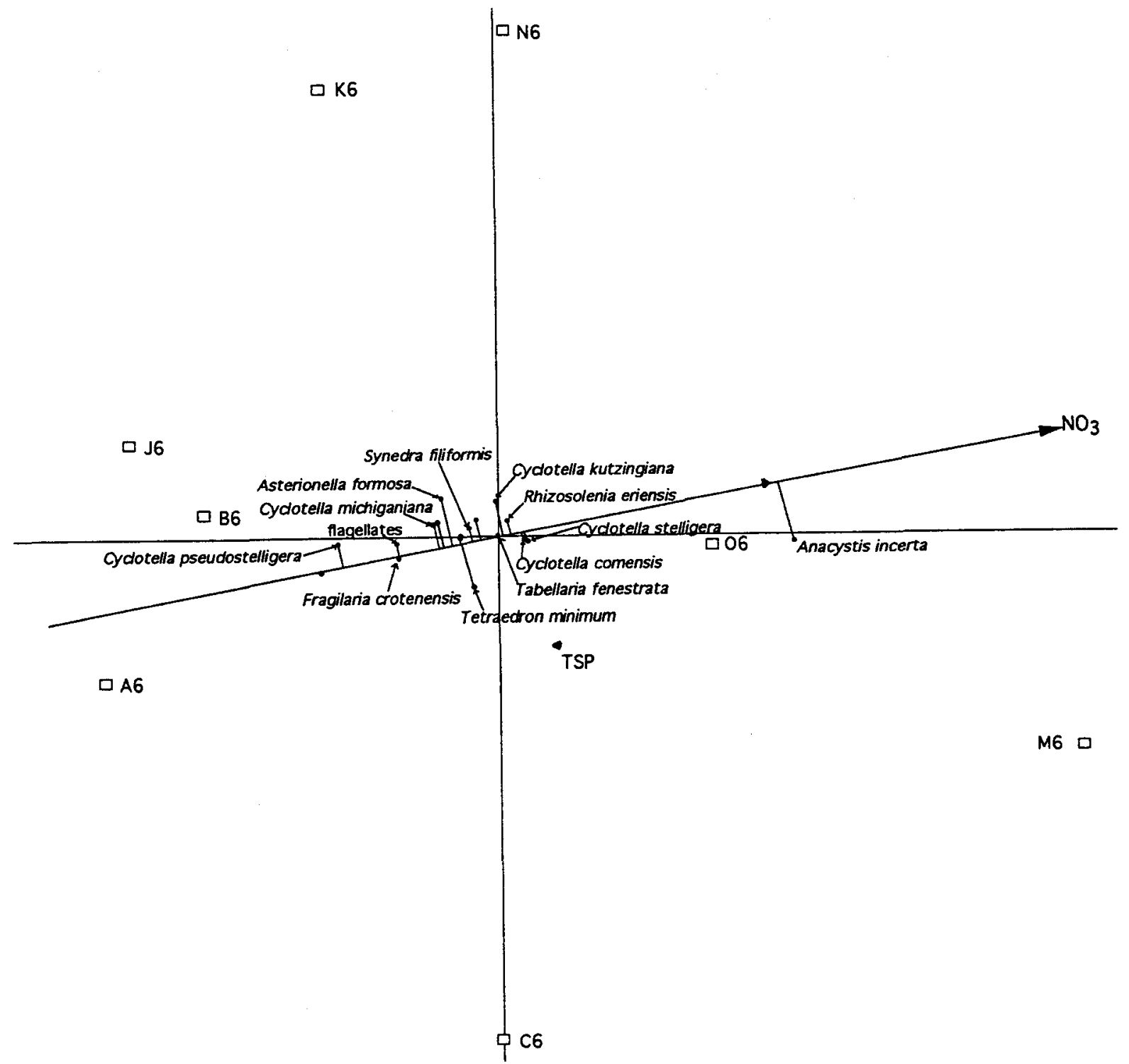

FIG. 3. CCA ordination diagram for Day 6 of the June 1991 experimental period. $\square$ represents sample scores, - represents species scores, and $\mathrm{NO}_{3}$ biplot score represented by arrow. Perpendiculars are depicted from species score to $\mathrm{NO}_{3}$ arrow.

phaeria lacustris and $G$. aponina occurred in detectable numbers only on Days 9,12 , and 18 .

A composite $\mathrm{CCA}$ was constructed to provide a concise picture of the species- $\mathrm{NO}_{3}$ relationship for the entire experimental period. The results from the Monte Carlo permutation test indicated that Days 6, 12 , and 15 were the only subsampling days in which significance could be attached to the results. Therefore, the composite CCA included all sample scores for these days. Mean species scores were calculated for those species which occurred in a majority of the experimental sampling days. A time gradient was evident on the first constrained axis starting with Day 6 on the left to Day 15 on the right (Fig. 4a). $\mathrm{A} \mathrm{NO}_{3}$ gradient from low to high followed the time gradient (Fig. 4b).

For the subsampling days depicted, species were influenced by mid $\mathrm{NO}_{3}$ concentrations for the most part with a secondary influence by mid TSP concentrations (Fig. 4c). Crucigenia quadrata and $C y-$ clotella pseudostelligera were negatively influenced by $\mathrm{NO}_{3}$. Asterionella formosa, C. ocellata, Rhizosolenia eriensis, C. michiganiana, Tabellaria fenestrata, Fragilaria crotonensis, Synedra filiformis, 
TABLE 1. Interset correlation coefficients for the two constrained axes of $\mathrm{NO}_{3}$ and TSP for each day of the June 1991 experimental period. Values are multiplied by $10^{3}$.

\begin{tabular}{|c|c|c|}
\hline $\begin{array}{c}\text { Day } 3 \\
\mathrm{NO}_{3} \\
\mathrm{TSP}^{2}\end{array}$ & $\begin{array}{r}902 \\
-352\end{array}$ & $\begin{array}{r}82 \\
-717\end{array}$ \\
\hline $\begin{array}{c}\text { Day } 6 \\
\mathrm{NO}_{3} \\
\text { TSP }\end{array}$ & $\begin{array}{l}778 \\
322\end{array}$ & $\begin{array}{r}172 \\
-716\end{array}$ \\
\hline $\begin{array}{c}\text { Day } 9 \\
\mathrm{NO}_{3} \\
\mathrm{TSP}\end{array}$ & $\begin{array}{l}-261 \\
-889\end{array}$ & $\begin{array}{r}711 \\
-121\end{array}$ \\
\hline $\begin{array}{c}\text { Day } 12 \\
\mathrm{NO}_{3} \\
\text { TSP }\end{array}$ & $\begin{array}{l}849 \\
153\end{array}$ & $\begin{array}{r}120 \\
-608\end{array}$ \\
\hline $\begin{array}{c}\text { Day } 15 \\
\mathrm{NO}_{3} \\
\mathrm{TSP}\end{array}$ & $\begin{array}{l}153 \\
836\end{array}$ & $\begin{array}{r}-887 \\
180\end{array}$ \\
\hline $\begin{array}{c}\text { Day } 18 \\
\mathrm{NO}_{3} \\
\mathrm{TSP}^{2}\end{array}$ & $\begin{array}{r}-701 \\
687\end{array}$ & $\begin{array}{l}429 \\
441\end{array}$ \\
\hline $\begin{array}{r}\text { Day } 20 \\
\mathrm{NO}_{3} \\
\mathrm{TSP} \\
\end{array}$ & $\begin{array}{r}685 \\
-804 \\
\end{array}$ & $\begin{array}{l}-525 \\
-286\end{array}$ \\
\hline
\end{tabular}

TABLE 2. Canonical eigenvalues after fitting covariables for each day of the June 1991 experimental period.

\begin{tabular}{llll}
\hline \hline & \multicolumn{3}{c}{$\begin{array}{c}\text { Canonical } \\
\text { Eigenvalues }\end{array}$} \\
\cline { 2 - 4 } & $\mathrm{AX1}$ & $\mathrm{AX2}$ & sum \\
\hline Day 3 & .09 & .03 & .12 \\
Day 6 & .097 & .005 & .102 \\
Day 9 & .076 & .014 & .09 \\
Day 12 & .128 & .073 & .201 \\
Day 15 & .06 & .051 & .11 \\
Day 18 & .134 & .016 & .15 \\
Day 20 & .073 & .06 & .133 \\
\hline
\end{tabular}

and Tetraedron minimum were not influenced by $\mathrm{NO}_{3}$. That is, their optima would occur with or without $\mathrm{NO}_{3}$ enrichment. Those species positively influenced by $\mathrm{NO}_{3}$ were flagellates, $C$. stelligera, $C$. comensis, Cyclotella sp., $F$. capucina, and $F$. pinnata.

From DCA an ordination was constructed to show species succession in the assemblage with re-
TABLE 3. Percentages of the species-environment relationship and variance for the species data for the first constrained axis for each day of the June 1991 experimental period.

\begin{tabular}{lcc}
\hline \hline & $\begin{array}{c}\text { \% Species- } \\
\text { environment } \\
\text { relation } \\
\text { explained }\end{array}$ & $\begin{array}{c}\text { \% Species } \\
\text { variance }\end{array}$ \\
\cline { 2 - 3 } & AX1 & AX1 \\
\hline Day 3 & 75.4 & 32.7 \\
Day 6 & 94.7 & 38.5 \\
Day 9 & 84.6 & 25.8 \\
Day 12 & 63.5 & 22.3 \\
Day 15 & 54.1 & 21.2 \\
Day 18 & 89.2 & 26.7 \\
Day 20 & 54.8 & 11.9 \\
\hline
\end{tabular}

TABLE 4. Results of Monte Carlo permutation test for each day of the June 1991 experimental period. Asterisked values indicate significance $(p<0.05)$.

\begin{tabular}{lll}
\hline \hline & \multicolumn{2}{c}{ Canonical } \\
& Eigenvalues \\
\cline { 2 - 3 } & AX1 & trace \\
\hline Day 3 & .08 & .13 \\
Day 6 & .03 & $.03^{*}$ \\
Day 9 & .16 & .09 \\
Day 12 & .36 & $.04^{*}$ \\
Day 15 & .25 & $.04^{*}$ \\
Day 18 & .29 & .25 \\
Day 20 & .89 & .66 \\
\hline
\end{tabular}

spect to time based on total species abundance for each treatment with subsampled days as passive sample variables to produce a time trajectory (Fig. 5). Except for Days 0 and 3, which represented initial nutrient levels and not the results of sustained additions, the time trajectory proceeded from left to right on a diagonal in the upper right quadrant of the ordination. This produced a time gradient for the first axis. The more subsampling days of the experiment that the species occurred at the $>1 \%$ abundance level, the nearer its species score occurred to the first axis.

From the start of the experiment to Day 6,Cyclotella comensis, C. ocellata, C. sp., C. michiganiana, Rhizosolenia eriensis, and Synedra filiformis dominated. From Day 6 to Day 15 flagellates were 
TABLE 5. Influence of $\mathrm{NO}_{3}$ on species. Approximate weighted averages of species with respect to $\mathrm{NO}_{3}$ biplot arrow from CCA ordination for each day of the June 1991 experimental period. Species order depicts ranking of species most influenced by $\mathrm{NO}_{3}$ at the top of the list to those least influence by $\mathrm{NO}_{3}$ at the bottom of the list.

\begin{tabular}{llll}
\hline \hline Day 3 & Day 6 & Day 9 & Day 12 \\
\hline Fragilaria crotonensis & Anacystis incerta & Fragilaria crotonensis & Fragilaria capucina \\
Crucigenia quadrata & Cyclotella stelligera & Cyclotella pseudostelligera & Fragilaria brevistriata var. inflata \\
Flagellates & Cyclotella comensis & Gleocystis planctonica & Fragilaria construens var. venter \\
Cyclotella comensis & Tabellaria fenestrata & Cyclotella ocellata & Cyclotella pseudostelligera \\
Fragilaria pinnata & Rhizosolenia eriensis & Asterionella formosa & Fragilaria crotonensis \\
Gleocystis planctonica & Cyclotella kuetzingiana & Tabellaria fenestrata & Cyclotella comensis \\
Synedra filiformis & Cyclotella ocellata & Cyclotella kuetzingiana & Flagellates \\
Tabellaria fenestrata & Synedra filiformis & Cyclotella sp. & Cyclotella michiganiana \\
Cyclotella stelligera & Tetraedron minimum & Diatoma tenue var. elongatum & Cyclotella stelligera \\
Asterionella formosa & Cyclotella \#6 & Cyclotella \#6 & Cyclotella sp. \\
Rhizosolenia eriensis & Cyclotella sp. & Flagellates & Cyclotella \#6 \\
Cyclotella kuetzingiana & Asterionella formosa & Synedra filiformis & Asterionella formosa \\
Cyclotella sp. & Cyclotella michiganiana & Cyclotella michiganiana & Tabellaria fenestrata \\
Cyclotella ocellata & Flagellates & Cyclotella stelligera & Synedra filiformis \\
Cyclotella michiganiana & Fragilaria crotonensis & Cyclotella comensis & Rhizosolenia eriensis \\
Fragilaria capucina & Cyclotella pseudostelligera & Rhizosolenia eriensis & Tetredron minimum \\
& & Tetraedron minimum & Cyclotella ocellata \\
& & Fragilaria capucina & Fragilaria pinnata \\
& & Gomphosphaeria lacustris & Gomphosphaeria lacustris
\end{tabular}

the dominant forms. From Day 15 to the end of the experiment, C. pseudostelligera, Tetraedron minimum, Fragilaria crotonensis, C. stelligera, Tabellaria fenestrata, Asterionella formosa, $F$. capucina, $F$. pinnata, and Crucigenia quadrata dominated.

Overall, Bacillariophyta, the diatoms, were overwhelmingly dominant during the experiment (Fig. 6). They reached maximum abundance on Day 9, decreased on Days 12 and 15, but increased on Days 18 and 20. Flagellates dominated on Day 6 as did chlorophytes and cyanophytes; thereafter, all these groups declined. However, on Day 18, cyanophytes and especially chlorophytes increased slightly in abundance.

From CA an ordination was constructed to illustrate the shift in dominance by division with respect to time based on total abundance (Fig. 6). The time gradient occurred on the first axis with early subsampling days on the left and later subsampling days on the right. The diatoms and chlorophytes had the largest abundances, and therefore occurred near the origin. Early in the experiment, flagellates domi- nated, then gave ground to the diatoms. Chlorophytes succeeded the diatoms with cyanophytes increasing toward the end of the experiment.

Effects from N:P provided additional evidence of influence on particular species. Overall, mean abundance did not change dramatically with respect to treatments (Fig. 7). For many of the dominant species, mean N:P did not affect mean abundance values (Figs. 8a-f). However, for Cyclotella comensis, flagellates, and Rhizosolenia eriensis, mean abundance occurred in the same pattern as treatments based on mean $\mathrm{N}: \mathrm{P}$ (Figs. 9a-c). When mean $\mathrm{N}: \mathrm{P}$ increased, the mean abundances increased. A decrease in mean abundance occurred when mean $\mathrm{N}: \mathrm{P}$ decreased. This is true with the exception of mean abundance for flagellates in treatment $A$.

For divisions, total abundance for Bacillariophyta was influenced with the exception of treatment $A$ (Fig. 10a). For Cyanophyta, treatments A-C and K, $\mathrm{M}, \mathrm{N}$, and $\mathrm{O}$ showed a mean $\mathrm{N}: \mathrm{P}$ influence (Fig. $10 \mathrm{~b}$ ). Only treatment $\mathrm{J}$ was the exception. There 
TABLE 5. Continued.

\begin{tabular}{|c|c|c|}
\hline Day 15 & Day 18 & Day 20 \\
\hline $\begin{array}{l}\text { Fragilaria construens } \\
\text { Fragilaria sp. } \\
\text { Crucigenia quadrata } \\
\text { Fragilaria capucina } \\
\text { Fragilaria pinnata } \\
\text { Tetredron minimum } \\
\text { Cyclotella \#6 } \\
\text { Synedra filiformis } \\
\text { Tabellaria fenestrata } \\
\text { Cyclotella sp. } \\
\text { Cyclotella michiganiana } \\
\text { Cyclotella comensis } \\
\text { Asterionella formosa } \\
\text { Flagellates } \\
\text { Cyclotella stelligera } \\
\text { Fragilaria crotonensis } \\
\text { Rhizosolenia eriensis } \\
\text { Cyclotella pseudostelligera } \\
\text { Cyclotella ocellata }\end{array}$ & $\begin{array}{l}\text { Crucigenia quadrata } \\
\text { Fragilaria constuens } \\
\text { Gomphosphaeria lacustris } \\
\text { Cyclotella pseudostelligera } \\
\text { Fragilaria brevistriata } \\
\text { Cyclotella ocellata } \\
\text { Rhizosolenia eriensis } \\
\text { Asterionella formosa } \\
\text { Synedra filiformis } \\
\text { Cyclotella comensis } \\
\text { Fragilaria crotonensis } \\
\text { Flagellates } \\
\text { Cyclotella stelligera } \\
\text { Tabellaria fenestrata } \\
\text { Cyclotella sp. } \\
\text { Cyclotella michiganiana } \\
\text { Oscillatoria sp. } \\
\text { Fragilaria capucina } \\
\text { Tetredron minimum } \\
\text { Fragilaria pinnata }\end{array}$ & $\begin{array}{l}\text { Botryococcus sp. } \\
\text { Fragilaria intermedia } \\
\text { Gleocystis planctonica } \\
\text { Achnanthes lauenburgiana } \\
\text { Scenedesmus } \mathrm{sp} . \\
\text { Cyclotella \#5 } \\
\text { Flagellates } \\
\text { Cyclotella ocellata } \\
\text { Fragilaria brevistriata } \\
\text { Anacystis incerta } \\
\text { Cyclotella } \text { sp. } \\
\text { Fragilaria crotonensis } \\
\text { Fragilaria capucina } \\
\text { Oscillatoria sp. } \\
\text { Asterionella formosa } \\
\text { Tabellaria fenestrata } \\
\text { Cyclotella michiganiana } \\
\text { Cyclotella stelligera } \\
\text { Cyclotella \#6 } \\
\text { Cyclotella comensis } \\
\text { Cyclotella comta } \\
\text { Crucigenia quadrata } \\
\text { Synedra filiformis } \\
\text { Fragilaria pinnata } \\
\text { Rhizosolenia eriensis }\end{array}$ \\
\hline
\end{tabular}

was no evident trend in mean $\mathrm{N}: \mathrm{P}$ influence on chlorophyte total abundance (Fig. 10c).

\section{DISCUSSION}

At the outset, $\mathrm{NO}_{3}$ levels were higher than anticipated in terms of proposed additions for the experiment. In this study, ambient $\mathrm{NO}_{3}$ concentration was $330 \mu \mathrm{g} \mathrm{L}^{-1}$ which exceeded past $\mathrm{NO}_{3}$ concentrations measured for the Great Lakes. This is consistent with other studies. In 1971, Lake Michigan had a $\mathrm{NO}_{3}$ concentration of $230 \mu \mathrm{g} \mathrm{L}^{-1}$ (Schelske et al. 1974). Rates of $\mathrm{NO}_{3}$ increases were $6.0 \mu \mathrm{g} \mathrm{L}^{-1} \mathrm{yr}^{-1}$ and $3.0 \mu \mathrm{g} \mathrm{L}^{-1} \mathrm{yr}^{-1}$ for Lakes Huron and Michigan, respectively (Stevens 1988). Lake Ontario $\mathrm{NO}_{3}$ concentrations increased by $9.4 \mu \mathrm{g} \mathrm{L}^{-1} \mathrm{yr}^{-1}$ between 1967 and 1982 (Stevens 1988). Lake Superior had a $\mathrm{NO}_{3}$ increase of $3 \mu \mathrm{g} \mathrm{L}^{-1} \mathrm{yr}^{-1}$ (Weiler 1978). Lake Erie showed a $7.5 \mu \mathrm{g} \mathrm{L}^{-1} \mathrm{yr}^{-1}$ increase in $\mathrm{NO}_{3}$ (International Joint Commission 1987).

Increases in $\mathrm{NO}_{3}$ levels have been evident as a result of phosphorus abatement programs (Slater and Bangay 1980). Evidence for atmospheric $\mathrm{NO}_{3}$ inputs was provided by this study. Treatment $P$ had rainwater additions which produced an increase in $\mathrm{NO}_{3}$ concentration of $120 \mu \mathrm{g} \mathrm{L}^{-1}$.

Biomass did not change greatly over time with $\mathrm{NO}_{3}$ enrichment as anticipated (Stoermer et al. 1978). The trend was exponential as expected (Schelske et al. 1974). The change in chlorophyll $a$ concentration from start to end of the experiment was approximately $4 \mu \mathrm{g} \mathrm{L}^{-1}$ (Fig. 1). By contrast, the 1971 Lake Michigan TSP enrichment experiment showed chlorophyll $a$ concentration ranging from $2 \mu \mathrm{g} \mathrm{L}^{-1}$ to $23 \mu \mathrm{g} \mathrm{L}^{-1}$, a change of $21 \mu \mathrm{g} \mathrm{L}^{-1}$ (Schelske et al. 1974).

There were definite responses to $\mathrm{NO}_{3}$ additions by individual species. Most notably, Cyclotella comensis showed a positive response to $\mathrm{NO}_{3}$ (Fig. 4c) as well as to $\mathrm{N}: \mathrm{P}$ (Fig. 9a). This corroborates similar findings from field studies (Stoermer and Kreis 1980, Stoermer et al. 1983). This taxon has been found in increasing abundance in recent years in the Great Lakes (Wolin 1992), particularly in 


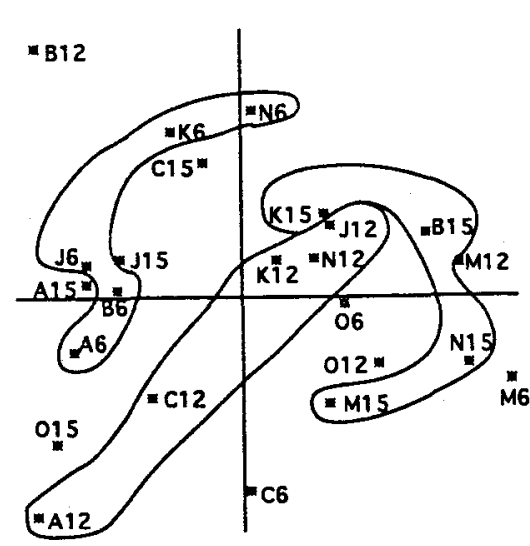

(a)

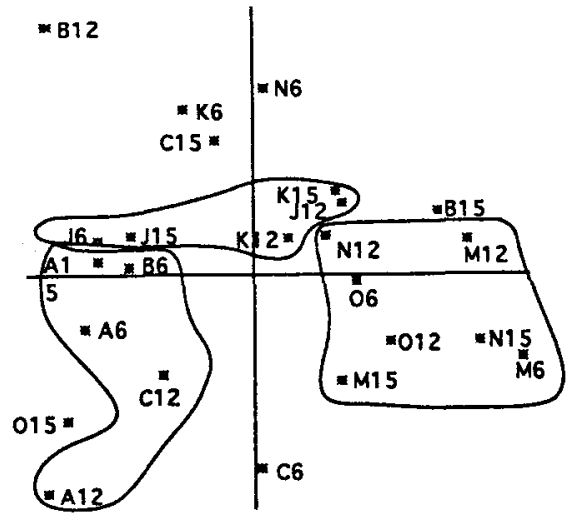

(b)

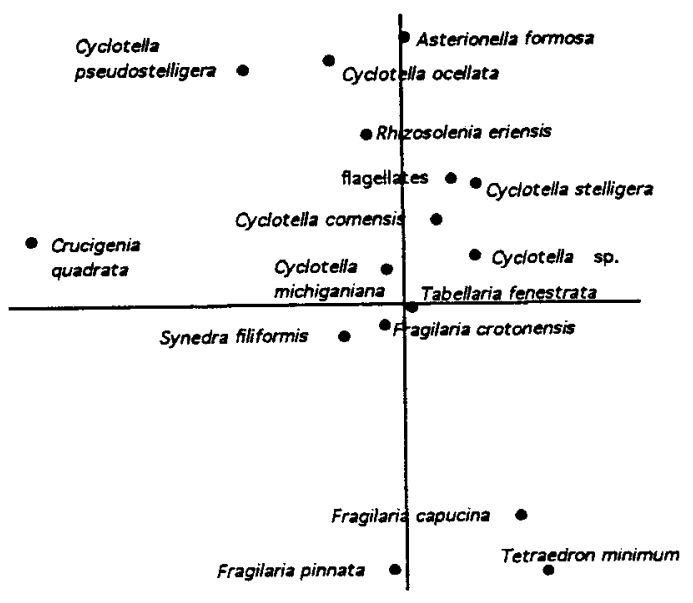

(c)

FIGS. 4a-c. Ordination diagrams for the June 1991 experimental period: (a) time gradient from left to right, where encircled regions represent Days 6, 12, and 15; (b) $\mathrm{NO}_{3}$ gradient from left to right, where encircled regions represent low, mid, and high $\mathrm{NO}_{3}$ concentrations; (c) mean species scores at mid $\mathrm{NO}_{3}$ concentrations.

Lake Huron (Wolin et al. 1988). In addition, $C$. comensis has been found in inland lakes in Michigan (Fritz et al. 1993). The results of this study strengthen the argument that $\mathrm{NO}_{3}$ is a causative factor.

There were changes in species composition with respect to time (Fig. 5). Early in the experiment when conditions in the treatments had not been established for very long, Cyclotella comensis, $C$. michiganiana, C. ocellata, and Cyclotella sp. were dominant. These species are representative of olig- otrophic conditions (Stoermer and Yang 1968, Stoermer et al. 1983). As already stated, C. comensis increased in abundance as a result of $\mathrm{NO}_{3}$ additions. Cyclotella michiganiana and C. ocellata were not affected. Rhizosolenia eriensis and Synedra filiformis, indicative of oligotrophic conditions, occurred near the start of the experiment. Neither species was affected by $\mathrm{NO}_{3}$ additions. Both species are tolerant of nutrient loadings (Stoermer et al. 1983). However, R. eriensis was affected by N:P (Fig. 9c). 


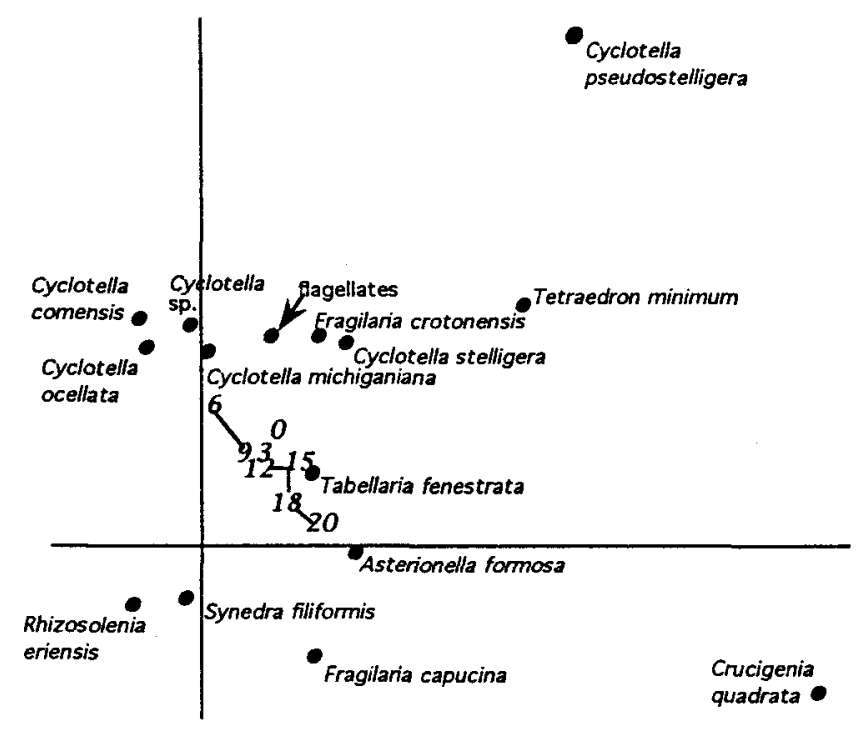

FIG. 5. DCA ordination of species succession over the course of the June 1991 experimental period. Trajectory depicts sequence of experimental subsampling days.

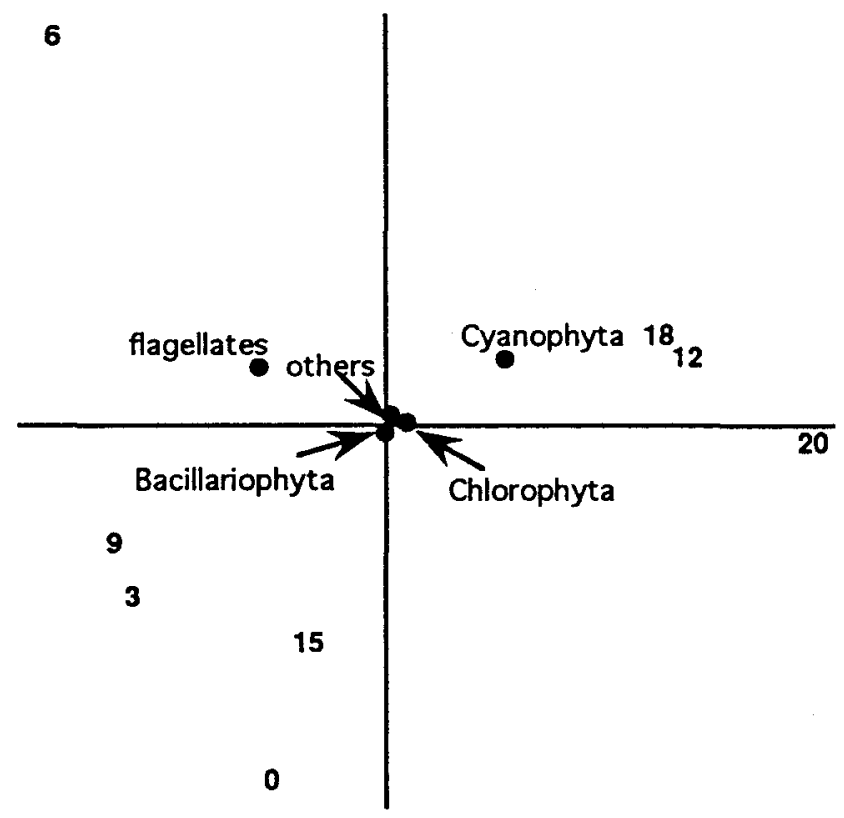

FIG. 6. CA ordination of divisional shift of dominance for the June 1991 experimental period.

Flagellates represented the dominant forms midway in the experiment. $\mathrm{NO}_{3}$ had a positive influence on flagellate abundance as did N:P. The effect of N:P influencing flagellate abundances has been found in previous studies (Schelske and Stoermer 1972).

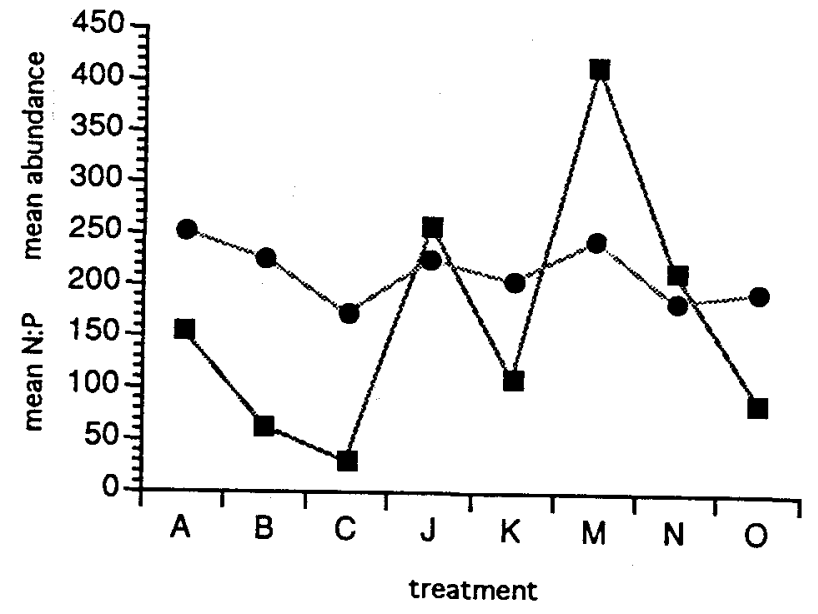

FIG. 7. Mean abundance for all species in relation to mean N:P for each treatment for the June 1991 experimental period. Line connection depicts pattern of the relationship, not continuity of data. represents treatments, 0 represents mean abundance for all species.

Cyclotella pseudostelligera and C. stelligera were dominant toward the end of the experiment after conditions had been well established. These species are typical of eutrophic conditions (Stoermer and Kreis 1980). They responded readily to nutrient additions. Unlike $C$. stelligera, $C$. pseudostelligera responded negatively to $\mathrm{NO}_{3}$; therefore, this taxon's increase in abundance may be attributed to phosphorus. Cyclotella stelligera is tolerant of varied conditions (Stoermer and Yang 1968), but responds positively only to slight nutrient enrichment (Stoermer et al. 1983).

In addition, $F$. capucina and $F$. pinnata were dominant near the end of the experiment. Fragilaria capucina is characteristic of eutrophic conditions (Stoermer and Kreis 1980, Stoermer et al. 1983). Fragilaria pinnata responded to the availability of nutrients (Stoermer and Kreis 1980). This taxon is primarily benthic, being associated with littoral habitats in the Great Lakes (Stoermer and Kreis 1980, Stoermer et al. 1983). At the same time Fragilaria crotonensis, Tabellaria fenestrata, and Asterionella formosa, which are tolerant of highly eutrophic conditions (Stoermer and Kreis 1980, Stoermer et al. 1983), were dominant.

Tetraedron minimum and Crucigenia quadrata were the only non-diatom dominants which occurred toward the end of the experiment. T. minimum responded neither positively nor negatively to 


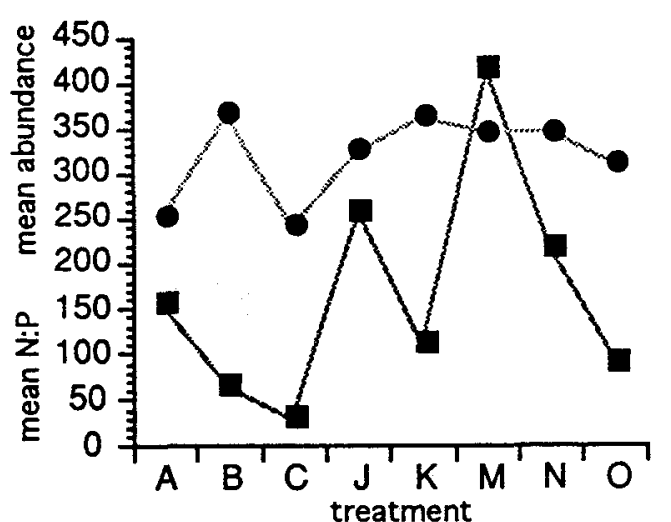

(a)

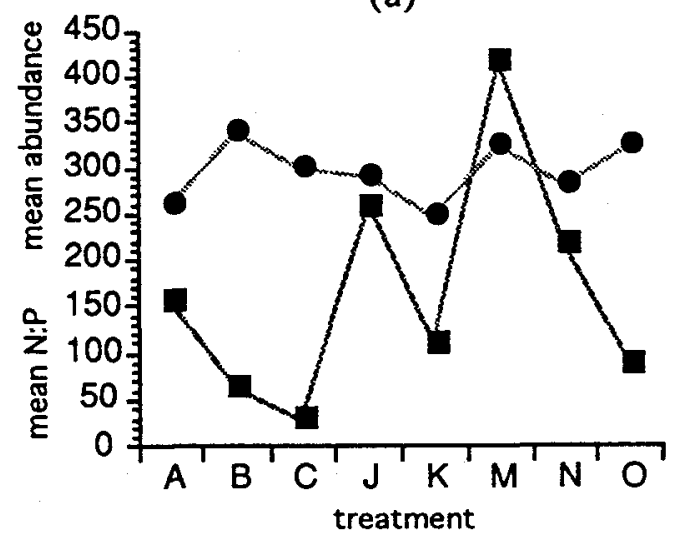

(c)

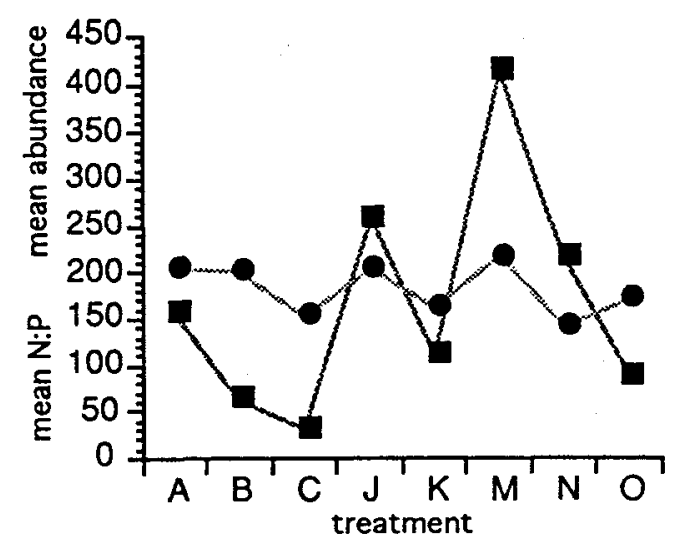

(e)

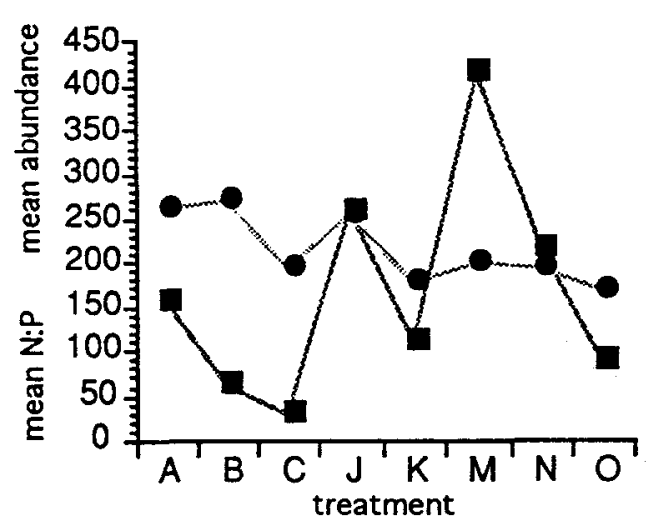

(b)

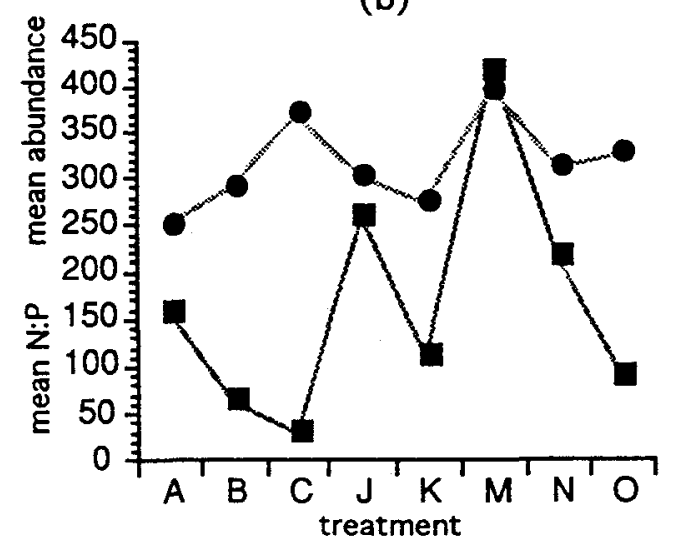

(d)

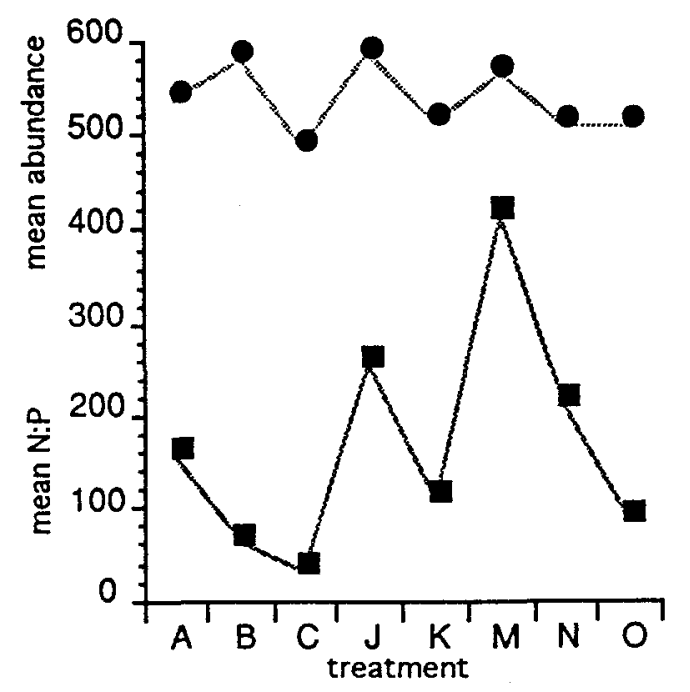

(f)

FIGS. 8a-f. Mean abundance in relation to mean N:P for each treatment for the June 1991 experimental period: (a) Asterionella formosa; (b) Cyclotella michiganiana; $(c)$ C. stelligera; $(d)$ Fragilaria crotonensis; $(e)$ Synedra filifomis; $(f)$ Tabellaria fenestrata. Line connection depicts pattern of the relationship, not continuity of data. represents treatments, represents mean abundance for all species. 


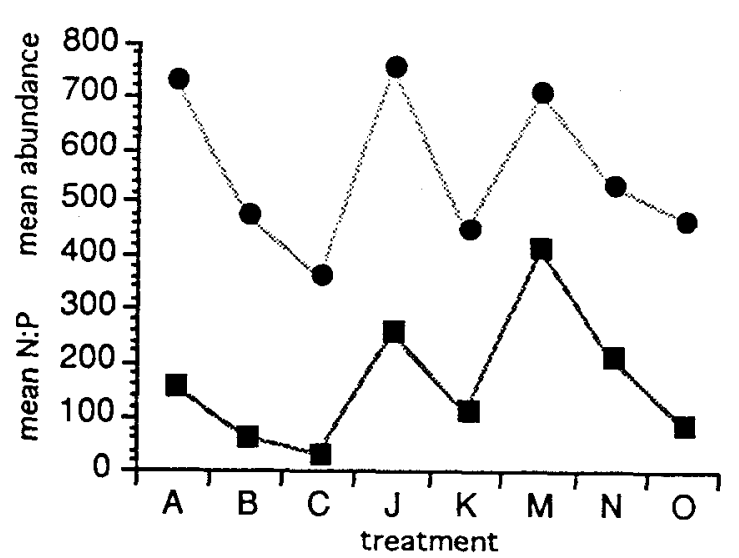

(a)

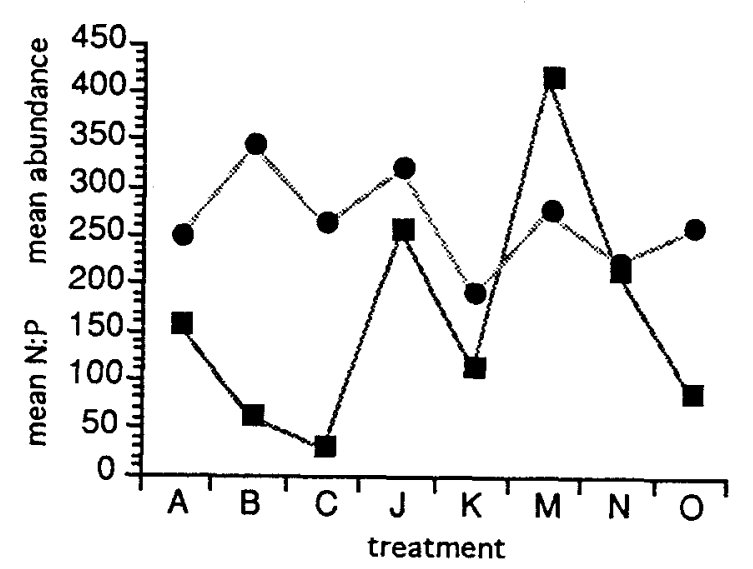

(b)

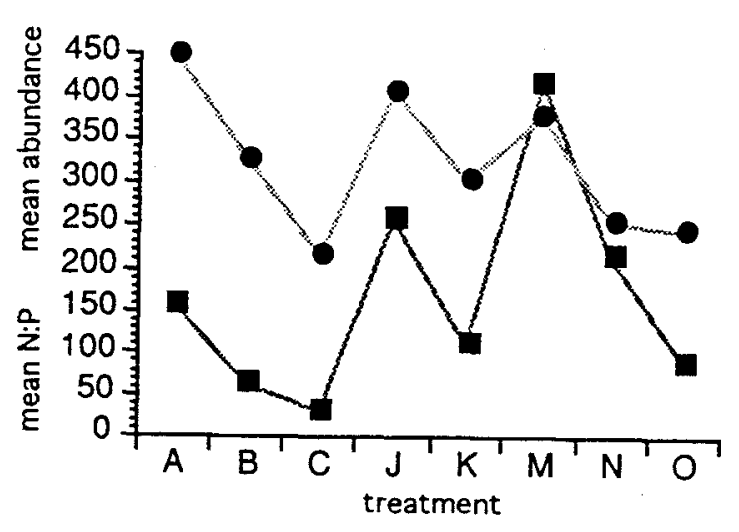

(c)

FIGS. 9a-c. Mean abundance in relation to mean N:P for each treatment for the June 1991 experimental period: (a) Cyclotella comensis; (b) flagellates; (c) Rhizosolenia eriensis. Line connection depicts pattern of the relationship, not continuity of data. 1 represents treatments, - represents mean abundance for all species.

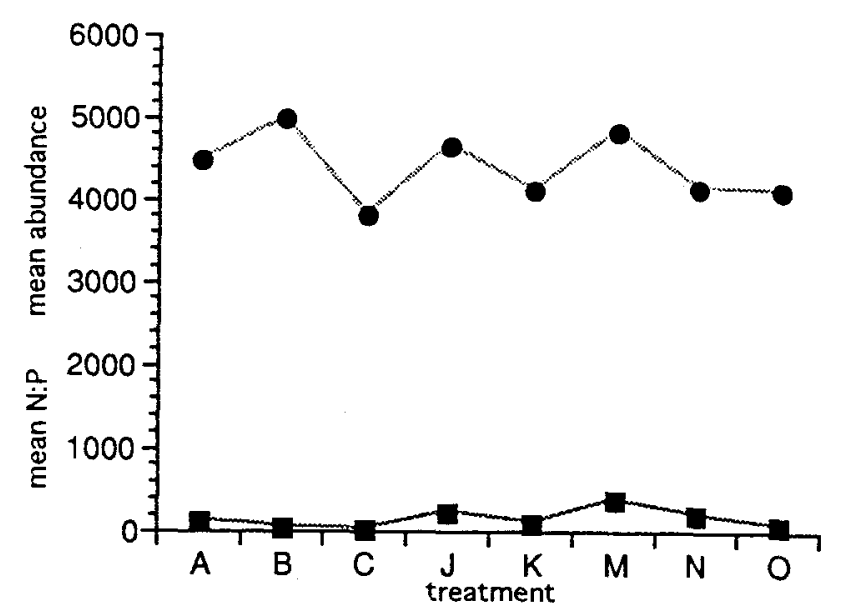

(a)

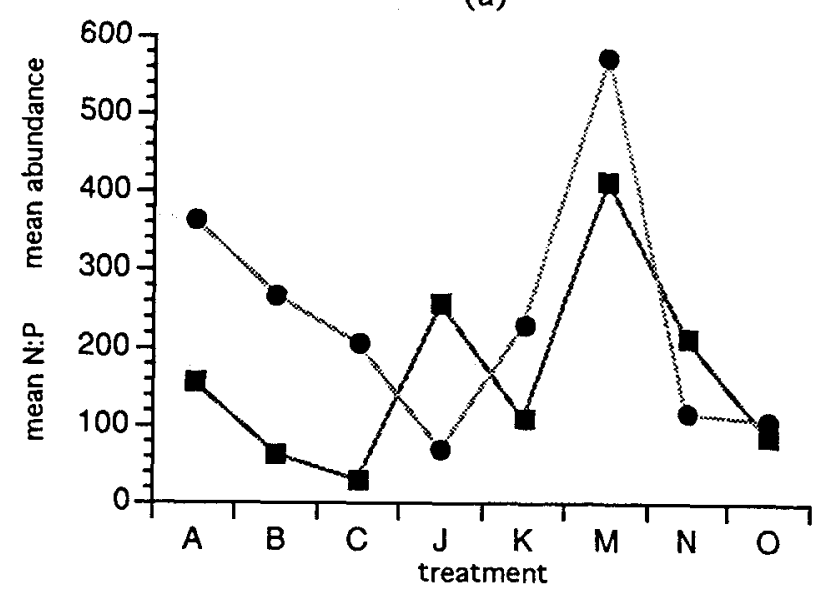

(b)

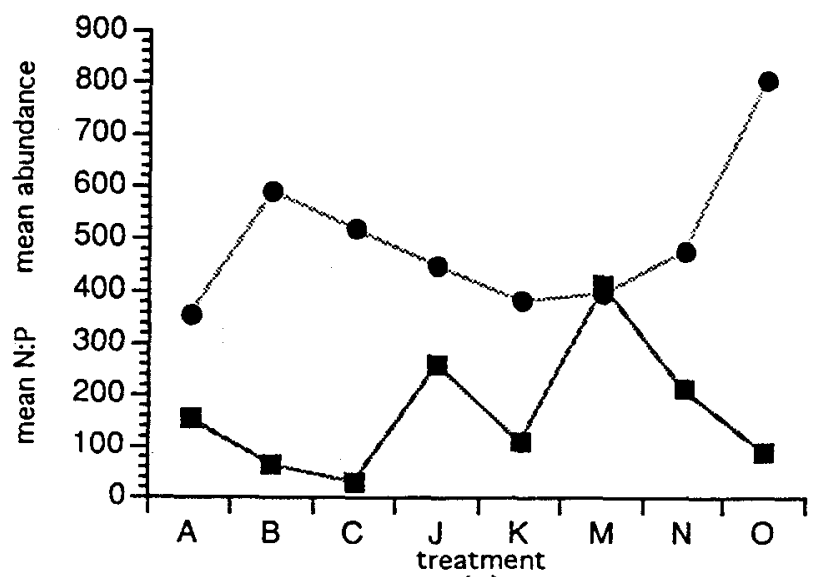

(c)

FIGS. 10a-c. Divisional total abundance in relation to mean $N: P$ for each treatment for the June 1991 experimental period: (a) Bacillariophyta; (b) Cyanophyta; (c) Chlorophyta. Line connection depicts pattern of the relationship, not continuity of data. 1 represents treatments, represents total divisional abundance. 
$\mathrm{NO}_{3}$ additions. This taxon is occasionally found in offshore waters, but it is associated with eutrophic conditions (Stoermer and Kreis 1980). C. quadrata was negatively affected by $\mathrm{NO}_{3}$ which implies that it responded to phosphorus availability. This taxon is typically sporadic in its distribution in southern Lake Huron (Stoermer and Kreis 1980).

The species abundance patterns found in this study may be compared to species patterns found in the Port Huron area of southern Lake Huron over approximately the past 20 years. Although this comparison should be viewed with caution, it may have interesting implications for possible species succession. In the 1974 and 1980 studies, a number of the taxa were the same as those found in this study. Some were not, including chlorophytes and cyanophytes. Since the groups common to all three studies are the diatoms and the flagellates, they will be the focus of discussion.

Overall, the dominant taxa for 1974 were Fragilaria capucina, F. crotonensis, and Cyclotella comensis. In the spring, Tabellaria fenestrata, $F$. crotonensis, and $F$. capucina were dominants, especially $F$. capucina. In the summer, flagellates dominated. In the fall, $F$. capucina and $C$. comensis dominated (Stoermer and Kreis 1980).

For 1980 , the overall dominant taxa were $F$. crotonensis and $C$. comensis. In the spring, $F$. capucina was the dominant taxa and Synedra filiformis was prevalent as well. In the summer, $C$. comensis and $F$. crotonensis prevailed. In the fall, $F$. capucina, $C$. comensis, and flagellates dominated (Stoermer et al. 1983).

In this study in the spring of $1991, C$. comensis, $T$. fenestrata, and $F$. capucina were the dominant taxa. From 1974 to $1991, F$. capucina exhibited continuity as a dominant form in the spring in southern Lake Huron. Over this time period, $C$. comensis has not only increased in abundance, but may also have changed the time at which it occurs in maximum numbers. If $\mathrm{NO}_{3}$ concentrations continue to increase, this may have an impact on the time of year $C$. comensis will appear in bloom quantities.

While changes at the species level were evident, there were minor changes in the dominance of divisions with respect to time (Fig. 6). Cyanophytes increased in abundance toward the end of the experiment. They showed a positive response to $\mathrm{NO}_{3}$ additions in spite of the overall dominance of the diatoms. In terms of $N: P$, both diatoms and cyanophytes showed a positive response. Some cyanophytes are highly tolerant of nutrient loadings as previously reported from Saginaw Bay in southern Lake Huron (Stoermer et al. 1983). As expected, flagellates dominated early in the experiment, then declined thereafter. Except for the flagellates, generally, the diatom, chlorophyte, and cyanophyte populations were maintained throughout the experiment.

\section{ACKNOWLEDGMENTS}

We appreciate technical assistance from Mark Edlund and Amy Ha. This research was supported by Grant R-816467 from the U. S. Environmental Protection Agency, Office of Exploratory Research.

\section{REFERENCES}

Bierman, V. J., and Dolan, D. M. 1986a. Modeling of phytoplankton in Saginaw Bay: I. Calibration phase. J. Environ. Eng. 112:400-414. , and Dolan, D. M. 1986b. Modeling of phytoplankton in Saginaw Bay: I. Post-audit phase. J. Environ. Eng. 112:415-429.

Brown, D. J. A. 1988. Effect of atmospheric N deposition on surface waters and the implications for fisheries. Environ. Pollution 54:275-284.

Dickson, W. 1982. Survey of acidification of Scandinavian freshwater systems; water chemistry of (airborne) $\mathrm{NO}_{\mathrm{x}}$. In Air Pollution by Nitrogen Oxides, $\mathrm{T}$. Schneider and L. Grant (eds.), pp. 555-565. Amsterdam: Elsevier Scientific Publishing Co.

1986. Critical loads for $\mathrm{N}$ on surface waters. In Critical Loads for Sulfur and Nitrogen, J. Nilsson (ed.), pp. 201-210. Nordisk ministerråd miljø rapport 11.

Dobson, H. F. H. 1984. Lake Ontario water chemistry atlas. Environment Canada, Inland Waters Directorate, National Water Research Institute, Canada Centre for Inland Waters, Burlington, Ontario, Scientific Series No. 139.

Fritz, S. C., Kingston, J. C., and Engstrom, D. R. 1993. Quantitative trophic reconstruction from sedimentary diatom assemblages: a cautionary tale. Freshwater Biology 30:1-23.

International Joint Commission. 1987. Report on Great Lakes water quality. Great Lakes Water Quality Board, Windsor, Ontario.

Likens, G. E. (ed.). 1972. Nutrients and eutrophication. American Society of Limnology and Oceanography, Inc., Special Symposium, Vol. I.

Makarewicz, J. C. 1987. Phytoplankton and zooplankton composition, abundance and distribution: Lake Erie, Lake Huron and Lake Michigan-1983. EPA-905/287-002. U. S. Environmental Protection Agency, Great Lakes National Program Office, Chicago, IL. 1988. Phytoplankton and zooplankton in Lake Erie, Lake Huron and Lake Michigan: 1984. EPA- 
905/3-88-001. U. S. Environmental Protection Agency, Great Lakes National Program Office, Chicago, IL.

Schelske, C. L., and Stoermer, E. F. 1971. Eutrophication, silica depletion and predicted changes in algal quality in Lake Michigan. Science 173:423-424.

, and Stoermer, E. F. 1972. Phosphorus, silica and eutrophication of Lake Michigan. In Nutrients and Eutrophication, G. E. Likens (ed.), pp. 157-171. American Society of Limnology and Oceanography Special Symposium Vol. I.

, Rothman, E. D., Stoermer, E. F., and Santiago,

M. A. 1974. Responses of phosphorus limited Lake Michigan phytoplankton to factorial enrichments with nitrogen and phosphorus. Limnol. Oceanogr. 19:409-419.

, Stoermer, E. F., Conley, D. J., Robbins, J. A., and Glover, R. M. 1983. Early eutrophication of the lower Great Lakes: New evidence from biogenic silica in the sediments. Science 222:320-322.

Slater, R. W. and Bangay, G. E. 1980. Action taken to control phosphorus in the Great Lakes. In Phosphorus Management Strategies for Lakes, R. C. Loehr, C. S. Martin, and W. Rast (eds.), pp. 13-26. Ann Arbor: Ann Arbor Science Publishers, Inc.

Smith, R. A., Alexander, R. B., and Wolman, M. G. 1987. Water-quality trends in the nation's rivers. Science 221:669-671.

Smith, V. H. 1983. Low nitrogen in phosphorus ratios favor dominance by blue-green algae in lake phytoplankton. Science 221:669-671.

Stevens, R. J. 1988. Response of Lake Ontario to reductions in phosphorus load: 1967-1982. In Rehabilitation of Lake Ontario: The Role of Nutrient Reduction and Food Web Dynamics. Report to the Great Lakes Science Advisory Board, International Joint Commission, Great Lakes Regional Office, Windsor, Ontario.

Stoermer, E. F., and Kreis, R. G., Jr. 1980. Phytoplankton composition abundance in southern Lake Huron. University of Michigan, Great Lakes Research Division, Special Report No. 65. , and Yang, J. J. 1968. A preliminary report of the fossil diatom flora from Lake Huron sediments. In Proceedings of the 11th Conference on Great Lakes Research, pp. 253-267. International Association for Great Lakes Research.

Schelske, C. L., and Feldt, L. E. 1971. Phytoplankton assemblage differences at inshore versus offshore stations in a Lake Michigan, and their effects on nutrient enrichment experiments. In Proceedings of the 14th Conference on Great Lakes Research, pp. 114-118. International Association for Great Lakes Research. , Ladewski, B. G., and Schelske, C. L. 1978. Population responses of Lake Michigan phytoplankton to nitrogen and phosphorus enrichment. Hydrobiologia 57:249-265.

Kreis, R. G., Jr., Theriot, E. C., and Ladewski, T. B. 1983. Phytoplankton abundance, species distribution, and community structure in Saginaw Bay and southern Lake Huron in 1980. EPA-600/S3-83-091. U.S. Environmental Protection Agency, Environmental Research Laboratory, Duluth, MN.

ter Braak, C.J.F. 1988. CANOCO-a FORTRAN program for canonical community ordination by [partial] [detrended] [canonical] correspondence analsis, principal components analysis and redundancy analysis (version 2.1). TNO Institute of Applied Computer Science, Wageningen, The Netherlands. 1990. Update notes: CANOCO version 3.10. Agricultural Mathematics Group, Wageningen, The 'Netherlands.

Weiler, R. R. 1978. Chemistry of Lake Superior. $J$. Great Lakes Res. 4:370-385.

Wolin, J. A. 1992. Paleoclimatic implications of late Holocene lake-level fluctuations in Lower Herring Lake, Michigan. Doctoral disseration, School of Natural Resources and Environment, University of Michigan. Stoermer, E. F., Schelske, C. L., and Conley, D. J. 1988. Siliceous microfossil succession in recent Lake Huron sediments. Archiv. Hydrobiol. 144:175-198.

Submitted: 6 August 1993

Accepted: 3 February 1995 